\title{
GAMBARAN TINGKAT STRES PADA LANSIA
}

\author{
Vindy Dortje Kaunang \\ Andi Buanasari \\ Vandri Kallo \\ Program Studi Ilmu Keperawatan Fakultas Kedokteran \\ Universitas Sam Ratulangi \\ Email: vindyvyn@gmail.com
}

\begin{abstract}
Elderly there is gradual physical and psychological deterioration, where the decline in conditions can cause stress to some elderly people. Psychosocial problems in the elderly can include stress, anxiety (anxiety) and depression. The problem comes from several aspects, including changes in physical, psychological and social aspects. This study was conducted to describe stress levels in the elderly at Badan Penyantunan Sosial Usia Terlantar Senja Cerah. Methods of this research is a descriptive survey research. The research was carried out at the Badan Penyantunan Sosial Usia Terlantar Senja Cerah in June to July 2019. This study used the Depression Anxiety Stress Scale 42 instrument which was changed to 20 questions. Univariate analysis to find out and describe the description of each variable consisting of age, type of sex, physical stress and psychological stress. These data are displayed in the form of frequency distribution tables and percentages. The results showed that of the 51 elderly in this study, 47 elderly (92.2\%) experienced mild physical stress. This study also found that of 51 elderly people in this study, 43 elderly (84.3\%) experienced mild psychological stress. In conclusion, the results of this study get an overview of physical and psychological stress in the elderly at the Balai Penyantunan Sosial Lanjut Usia Terlantar Senja Cerah.
\end{abstract}

Keywords: Physical Stress, Psychological Stress, Elderly.

Abstrak: Lansia terjadi kemunduran fisik dan psikologis secara bertahap, dimana penurunan kondisi tersebut dapat menimbulkan stres pada sebagian lansia. Masalah psikososial pada lansia dapat berupa stres, ansietas (kecemasan) dan depresi. Masalah tersebut bersumber dari beberapa aspek, diantaranya perubahan aspek fisik, psikologis dan social. Penelitian ini dilakukan untuk mengetahui gambaran tingkat stress pada lansia di Balai Penyantunan Sosial Lanjut Usia Terlantar Senja Cerah. Metode penelitian ini merupakan penelitian survei deskriptif. Penelitian telah dilaksanakan di Balai Penyantunan Sosial Lanjut Usia Terlantar Senja pada Juni sampai dengan Juli 2019. Penelitian ini menggunakan instrumen Depression Anxiety Stres Scale 42 yang dirubah menjadi 20 pertanyaan. Analisis univariat untuk mengetahui dan mendeskripsikan gambaran pada masing-masing variabel yang terdiri dari umur, jenis kelamin, stress fisik dan stress psikologi. Data-data tersebut ditampilkan dalam bentuk tabel distribusi frekuensi dan persentasi. Hasil penelitian menunjukkan bahwa dari 51 lansia dalam penelitian ini, sebanyak 47 lansia $(92,2 \%)$ mengalami stress fisik ringan. Penelitian ini juga mendapatkan dari 51 lansia dalam penelitian ini, sebanyak 43 lansia $(84,3 \%)$ mengalami stress psikologis ringan. Kesimpulan, hasil penelitian ini mendapatkan gambaran stress fisik dan psikologis pada lansia di Balai Penyantunan Sosial Lanjut Usia Terlantar Senja Cerah.

Kata Kunci: Stres Fisik, Stres Psikologis, Lansia. 


\section{PENDAHULUAN}

Penuaan merupakan suatu proses natural, penuaan akan terjadi pada semua sistem tubuh manusia dan tidak semua system akan mengalami kemunduran pada waktu yang sama. Meskipun proses menjadi tua merupakan gambaran yang universal, namun tidak seorangpun mengetahui dengan pasti penyebab penuaan atau mengapa manusia menjadi tua pada usia yang berbeda-beda (Fatmawati dan Imron, 2017).

Manusia berkembang dari ketidakberdayaan hingga menjadi manusia yang sempurna dan mandiri, dan akhirnya menjadi renta tak berdaya lagi. Akan tetapi, ada sebagian orang yang takut dan tidak mau menerima kenyataannya serta tak tahu harus bagaimana menghadapi masa lanjut usianya. Betapa banyak orang lanjut usia yang merasa kesepian dan tak berguna, dan tak sedikit pula yang mengalami stress (Rahman, 2016).

Batasan lansia merupakan seseorang yang telah berusia 60 tahun atau lebih. Dalam Undang-undang No. 13 tahun 1998 tentang kesejahteraan lansia, yang termasuk lansia adalah seseorang yang telah ber-usia 60 tahun atau lebih. Berdasar hasil Susenas tahun 2013, jumlah lansia di Indonesia men-capai 20,04 juta orang atau sekitar 8,05 persen dari seluruh penduduk Indonesia (BPS, 2013).

Lansia terjadi kemunduran fisik dan psikologis secara bertahap, dimana penurunan kondisi tersebut dapat menimbulkan stres pada sebagian lansia. Masalah psikososial pada lansia dapat berupa stres, ansietas (kecemasan) dan depresi. Masalah tersebut bersumber dari beberapa aspek, diantaranya perubahan aspek fisik, psikologis dan sosial. Gejala yang terlihat pada lansia dapat berupa emosi labil, mudah tersinggung, gampang merasa dilecehkan, kecewa, tidak bahagia, perasaan kehilangan, dan perasaan tidak berguna. Walaupun tidak disebutkan lebih terperinci mengenai angka kejadian dari masing-masing masalah psikososial tersebut, namun dari penjelasan tersebut dapat diketahui bahwa perubahanperubahan yang terjadi pada lansia dapat berkembang menjadi masalah-masalah lain yang seringkali juga disertai dengan terjadinya perubahan konsep diri (Hurlock, 2004).

Stres merupakan reaksi fisiologis dan psikologis yang terjadi jika seseorang merasakan ketidakseimbangan antara tuntutan yang dihadapi dengan kemampuan untuk mengatasi tuntutan tersebut. Stres dapat dikatakan adalah gejala penyakit masa kini yang erat kaitannya dengan adanya kemajuan pesat dan perubahan yang menuntut adaptasi seseorang terhadap perubahan tersebut dengan sama pesatnya. Usaha, kesulitan, hambatan, dan kegagalan dalam mengikuti derap kemajuan dan perubahannya menimbulkan beraneka ragam keluhan (Rahman, 2016).

Penelitian yang dilakukan oleh Azizah dan Hartanti (2016) mendapatkan bahwa sebagian besar lansia mengalami stress dalam katagori sedang. Hasil penelitian ini sejalan dengan teori yang menyebutkan bahwa pada umumnya lansia akan mengalami stress, kecemasan dan depresi yang dapat terjadi gangguan baik fisik, mental maupun sosial. Dilihat dari segi mental lansia dengan stress akan menjadi pemarah, pemurung, sering merasa cemas dan lain sebagainya. Dampak dari lansia yang mengalami stress adanya penurunan kualitas hidup lansia dengan hipertensi di wilayah kerja Puskesmas Wonopringgo Kabupaten Pekalongan.

Hasil penelitian yang dilakukan oleh Selo, dkk (2017) mendapatkan bahwa sebagian besar $(40,7 \%)$ lansia yang tinggal di Panti Wrdha Pangesti Lawang mengalami stress sedang sedangkan lansia yang tinggal di luar Panti Werdha Pangesti Lawang sebagian besar $(47,6 \%)$ tidak mengalami stress. Hal ini dikarenakan lansia tidak tinggal dengan keluarga sehingga lansia kemungkinan dalam hidupnya merasa sendiri dan tidak ada yang memberi semangat. Umumnya stress yang berlarut-larut dapat menimbulkan perasaan cemas, takut, tertekan, kehilangan rasa 
aman, harga diri terancam, gelisah, keluar keringat dingin, jantung sering berdebardebar, pusing, sulit atau suka makan dan sulit tidur. Kecemasan yang berat dan berlangsung lama akan menurunkan kemampuan dan efisiensi seseorang dalam menjalankan fungsi-fungsi hidupnya dan pada akhirnya dapat menimbulkan berbagai macam gangguan jiwa. Banyak yang kita temukan lansia yang dikirim ke panti jompo dan tidak terurus keluarga, ada lansia yang diasingkan dari kehidupan anak cucunya meskipun hidup dalam kehidapan yang sama dan ada lansia yang masih harus bekerja keras meskipun sudah tua (Musradinur, 2016).

Dampak stres umumnya yang jika tidak dapat diatasi oleh lansia dapat menyebabkan lansia mengalami kemunduran fisik. Kemunduran fisik terjadi karena lansia memikirkan dan mempunyai persepsi buruk terhadap perubahan yang terjadi pada dirinya. Keadaan ini yang mempengaruhi kualitas hidup lansia (Putri, 2012). Berdasarkan survei pendahuluan yang dilakukan oleh peneliti mendapatkan bahwa jumlah lansia yang ada di Balai Penyantunan Sosial Lanjut Usia Terlantar Senja Cerah sebanyak 51 lansia. Sebanyak 4 lansia yang diambil pada survei awal mengalami gejala stress fisik berupa lansia mudah merasa letih, merasa lemas seperti mau pingsan, nafsu makan yang berubah-ubah dan tidak mampu untuk melakukan suatu kegiatan. Dari survei awal ini juga menunjukkan ada 5 lansia mengalami gejala stress psikologis seperti mudah tersinggung, gelisah, mudah marah dan sulit untuk beristirahat. Penelitian ini tidak mengambil stress kimiawi dikarenakan menurut petugas disana pemberian obat-obatan tidak rutin.

\section{METODE PENELITIAN}

Penelitian ini merupakan penelitian survei deskriptif. Penelitian telah dilaksanakan di Balai Penyantunan Sosial Lanjut Usia Terlantar Senja pada Juni sampai dengan Juli 2019. Penelitian ini menggunakan instrumen Depression
Anxiety Stres Scale 42 yang dirubah menjadi 20 pertanyaan, terdiri dari 4 pertanyaan tentang stress fisik dengan skor jika jawaban "tidak pernah" bernilai 4, "kadang-kadang" bernilai 3, "sering" bernilai 2, dan "selalu" bernilai 1. Katagori penilaian stress fisik dibagi: stres fisik ringan 12-16, stress fisik sedang 7-11, dan stres fisik berat 1-6.

Stres Psikologis terdiri dari 16 pertanyaan dengan skor "tidak pernah" bernilai 4, "kadang-kadang" bernilai 3, "sering" bernilai 2, dan "selalu" bernilai 1 . Katagori penilaian stres psikologis dibagi : stres psikologis ringan 45-64, stres psikologis sedang 23-44, dan stress psikologis berat 1-22. Dalam penelitian ini didapatkan populasi yaitu sebanyak 51 lansia dengan tolal sampling yaitu dimana jumlah sampel yang digunakan adalah seluruh total populasi yaitu sebanyak 51 responden. Analisis univariat untuk mengetahui dan mendeskripsikan gambaran pada masing-masing variabel yang terdiri dari umur, jenis kelamin, stress fisik dan stress psikologi. Data-data tersebut ditampilkan dalam bentuk tabel distribusi frekuensi dan persentasi.

\section{HASIL dan PEMBAHASAN}

Tabel 1. Gambaran Stress Fisik pada Lansia di Balai Penyantunan Sosial Lanjut Usia Terlantar Senja Cerah

\begin{tabular}{ccc}
\hline Stres Fisik & n & \% \\
\hline Ringan & 47 & 92,2 \\
Sedang & 4 & 7,8 \\
\hline Total & $\mathbf{5 1}$ & $\mathbf{1 0 0 , 0}$ \\
\hline
\end{tabular}

Sumber :Data Primer 2019

Hasil penelitian diatas dapat diketahui bahwa dari 51 lansia dalam penelitian ini, sebanyak 47 lansia (92,2\%) mengalami stress fisik ringan. Berdasarkan penelitian ini menunjukkan bahwa sebagian besar lansia mengalami stress fisik ringan. Hal ini disebabkan karena para lansia kadang bahkan tidak pernah mengalami kelelahan padahal tidak mengerjakan hal-hal yang melelahkan, detak jantung meningkat setelah melakukan aktivitas, cenderung 
bereaksi berlebihan terhadap suatu situasi misalnya berbicara lebih cepat dan merasa telah menghabiskan banyak energi.

Penelitian ini masih ditemui lansia yang mengalami stress fisik sedang disebabkan para lansia sering mengalami kelelahan padahal tidak mengerjakan halhal yang melelahkan. Hal ini sesuai dengan teori Kamso (2000) dalam Karepouwan, dkk (2018) dimana lanjut usia terjadi penurunan kekuatan sebesar $88 \%$, pendengaran $67 \%$, penglihatan $72 \%$, daya ingat $61 \%$, serta kelenturan yang menurun sebesar $64 \%$. Jadi walaupun tidak atau jarang melakukan aktivitas fisik yang berat lansia pasti merasakan kelelahan dan menghabiskan banyak energi. Hasil ini sesuai dengan Rahman (2016) dimana aspek-aspek stres meliputi gejala stres yang berkaitan dengan kondisi dan fungsi tubuh dari seseorang, seperti; sakit kepala, sulit tidur, banyak melakukan kekeliruan dalam kerja. Gejala-gejala stress fisik seperti sakit kepala, nyeri otot, sakit punggung, rasa lemah, gangguan pencernaan, rasa mual atau muntah-muntah, sakit perut, nafsu makan hilang atau selalu ingin makan, jantung berdebar-debar, sering buang air kecil, tekanan darah tinggi, tidak dapat tidur atau tidur berlebihan, berkeringat secara berlebihan dan sejumlah gejala lain.

Proses penuaan mengakibatkan perubahan (penurunan) struktur dan fisiologis pada lanjut usia seperti : penglihatan, pendengaran, sistem paru, persendian tulang. Seiring dengan penurunan fungsi fisiologis tersebut, ketahanan tubuh lansia pun semakin menurun sehingga terjangkit berbagai penyakit. Penurunan kemampuan fisik ini dapat menyebabkan lansia menjadi stress, yang dulunya semua pekerjaan bisa dilakukan sendirian, kini terkadang harus dibantu orang lain. Perasaan membebani orang lain inilah yang dapat menyebabkan stress.

Orang dikatakan lansia jika usianya lebih dari 60 tahun. Pada lansia mengalami proses penuaan yang mengakibatkan perubahan-perubahan fungsi pada lansia, salah satunya adalah penurunan fungsi kognitif. Semakin bertambahnya usia seseorang maka kecepatan proses di pusat saraf semakin menurun yang dapat mengakibatkan perubahan penurunan fungsi kognitif. Kemunduran fungsi kognitif sebelum usia 50 tahun adalah abnormal dan patologis. Perubahan fungsi kognitif dialami hampir semua orang yang mencapai usia 70-an tahun. Pada usia 65-75 tahun didapati kemunduran pada beberapa kemampuan. Di atas usia 80 tahun didapati kemunduran yang cukup banyak (Bandiyah, 2009).

Lansia yang menderita penyakit dapat mengakibatkan perubahan fungsi fisiologis pada orang yang menderitanya. Perubahan fungsi tersebut dapat mempengaruhi kehidupan seseorang dapat menyebabkan stress pada kaum lansia yang mengalaminya. Perubahan fungsi fisiologis yang dialami seseorang tergantung pada penyakit yang dideritanya. Semakin sehat jasmani lansia semakin jarang ia terkena stress, dan sebaliknya, semakin mundur kesehatannya, maka semakin mudah lansia itu terkena stress. Para lansia yang rentan terhadap stress misalnya lansia dengan penyakit degeneratif, lansia yang menjalani perawatan lama di rumah sakit, lansia dengan keluhan somatis kronis, lansia dengan imobilisasi berkepanjangan serta lansia dengan isolasi sosial (Hidaayah, 2013).

Banyak faktor yang mempengaruhi tingkat stress lansia yang tinggal di panti. Ketika berbicara tentang faktor yang mempengaruhi tingkat stres, kita tidak bisa lepas dari sumbersumber penyebab stres atau yang biasa disebut dengan stresor. Stresor merupakan semua faktor yang mempengaruhi timbulnya stress yang mengganggu keseimbangan dalam tubuh (Padila, 2013). Sebagian penyebab stress lansia di panti ialah mudah merasa lelah padahal tidak melakukan pekerjaan yang melelahkan. Semakin tua umur maka akan terjadi penurunan kekuatan yang sangat besar. Walaupun tidak melakukan aktivitas 
fisik yang berat para lansia akan tetap merasakan kelelahan.

Gejala stress fisik dapat berupa sakit kepala, pusing, pening, tidur tidak teratur, insomnia (susah tidur), bangun terlalu awal, sakit punggung, terutama dibagian bawah, urat tegang terutama pada leher dan bahu, tekanan darah tinggi atau serangan jantung, selera makan yang berubah, mudah lelah atau kehilangan daya energi, dan bertambah banyak melakukan kekeliruan atau kesalahan kerja dan hidup (Rahman, 2016). Penurunan fisik umum dialami lansia, misalnya penurunan sistem imun yang cenderung menurun, penurunan sistem integumen yang menyebabkan kulit mudah rusak, perubahan elastisitas arteri pada sistem kardiovaskular yang dapat memperberat kerja jantung, penurunan kemampuan metabolisme oleh hati dan ginjal, serta penurunan kemampuan penglihatan dan pendengaran. Perubahan fisik yang cenderung mengalami penurunan tersebut akan menyebabkan berbagai gangguan secara fisik yang ditandai dengan ketidakmampuan lansia untuk beraktivitas atau melakukan kegiatan yang tergolong berat sehingga mempengaruhi kesehatan serta akan berdampak pada kualitas hidup lansia (Ummah, 2016).

Tabel 2. Gambaran Stres Psikologis pada Lansia di Balai Penyantunan Sosial Lanjut Usia Terlantar Senja Cerah

\begin{tabular}{ccc}
\hline $\begin{array}{c}\text { Stres } \\
\text { Psikologis }\end{array}$ & $\mathbf{n}$ & $\boldsymbol{\%}$ \\
\hline Ringan & 43 & 84,3 \\
Sedang & 8 & 15,7 \\
\hline Total & $\mathbf{5 1}$ & $\mathbf{1 0 0 , 0}$ \\
\hline
\end{tabular}

Sumber : Data Primer 2019

Tabel di atas dapat diketahui bahwa dari 51 lansia dalam penelitian ini, sebanyak 43 lansia $(84,3 \%)$ mengalami stress psikologis ringan. Hasil penelitian ini menunjukkan bahwa sebagian besar lansia mengalami stress psikologis ringan. Hal ini disebabkan karena para lansia kadang bahkan tidak pernah mengalami merasa terganggu oleh baying-bayang masa lalu yang buruk, marah karena hal yang sepele, sulit bersantai, mudah tersinggung, sulit merasa tenang, merasa ketakutan tanpa ada alasan yang jelas, merasa kesepian, mudah gelisah, sulit untuk beristirahat, merasa hidup sudah tidak berarti lagi, mudah marah, jika merasa tertekan tidak melakukan kegiatan apapun, tidak sabar ketika mengalami penundaan, merasa kehilangan minat, mudah menangis serta tidak bisa dihibur dengan apapun jika merasa sedih.

Penelitian ini masih ditemui lansia yang mengalami stress psikologis sedang dimana para lansia sering mengalami mudah tersinggung, mudah marah karena hal-hal yang sepele. Menurut asumsi peneliti, sebagian besar lansia masih memiliki keluarga akan tetapi keluarga jarang berkunjung sehingga membuat sebagian lansia merasa sudah tidak berarti bagi keluarganya. Hasil ini sesuai dengan pendapat Arbi dan Ambarini (2018) dimana stress psikologis disebabkan oleh gangguan struktur, fungsi jaringan, organ, atau sistemik sehingga menimbulkan fungsi tubuh tidak normal. Stres proses pertumbuhan dan perkembangan, disebabkan oleh gangguan pertumbuhan dan perkembangan pada masa bayi hingga tua. Penyebab stres psikologis seperti labelling dan prasangka, ketidak kepuasan terhadap diri sendiri terhadap suatu hal yang dialami, kekejaman, konflik peran, percaya diri yang rendah, perubahan ekonomi, emosi yang negatif, dan kehamilan.

Stres psikologis merupakan stres yang disebabkan karena gangguan situasi psikologis atau ketidakmampuan kondisi psikologis untuk menyesuaikan diri seperti hubungan interpersonal, sosial budaya atau faktor keagamaan. Individu sering menggunakan keadaan emosionalnya untuk mengevaluasi stres. Proses penilaian kognitif dapat mempengaruhi stres dan pengalaman emosional. Reaksi emosional terhadap stres yaitu rasa takut, fobia, kecemasan, depresi, perasaan sedih dan 
rasa marah. Dampak negatif stres seperti tekanan darah tinggi, pusing, sedih, sulit berkonsentrasi, tidak bisa tidur seperti biasanya, terlampau sensitif, depresi, dan lainnya serta dalam kondisi tertentu, stres bisa menimbulkan berbagai keluhan (Musradinur, 2016).

Gelisah atau cemas, sedih, depresi, menangis, mood atau suasana hati sering berubah-ubah, mudah panas atau cepat marah, harga diri menurun atau merasa tidak aman, terlalu peka dan mudah tersinggung, gampang menyerah dan sikap bermusuhan, emosional atau kehabisan sumber daya mental (burn out) merupakan gejala-gejala dari stress psikologis (Sary, 2015). Lansia yang mengalami stres emosi seperti merasa khawatir dengan masalah yang tidak jelas, merasa letih, bangun tidur badan terasa sakit, merasa capek, merasa jantung berdebar akan menyebabkan kualitas tidur yang menurun. Lansia yang mengalami stres akan mengalami kualitas tidur yang buruk. Depresi dan kecemasan seringkali mengganggu tidur. Seseorang yang dipenuhi dengan masalah mungkin tidak bisa rileks untuk bisa tidur. Kecemasan akan meningkatkan kadar norepinephrin dalam darah yang akan merangsang sistem saraf simpatetik (Dahroni, dkk, 2017).

Kondisi psikologis lansia, misalnya pengalaman, sifat, jenis kepribadian dan cara pandang. dapat berpengaruh dalam menghadapi stress. Cara pandang lansia yang yang positif dalam menghadapi masalah, dapat menyelesaikan masalah tersebut melalui proses mekanisme penyelesaian yang positif pula. Berorientasi pada masalah, selalu mencari jalan tengah, berdasarkan pertimbangan pengalaman yang baik maupun kurang baik. Orang yang selalu menyikapi positif segala tekanan hidup akan kecil resiko terkena stress (Rahman, 2016).

Inti dari kesuksesan dimasa lansia adalah kemampuan untuk beradaptasi terhadap berbagai perubahan dan peristiwa hidup yeng membawa perubahan ternyata belum bisa dilakukan oleh seluruh lansia subyek penelitian ini Tingkat strss yang tinggi menunjukkan ketidakmampuan mereka dalam menyesuaikan terhadap berbagai perubahan tersebut. Tanggung jawab selanjutnya berada pada caregivers atau pihak-pihak di sekitar lansia atara lain pengurus panti, keluarga, teman-teman, maupun helper untuk membantu para lansia panti menjalani masa tuanya dengan sukses atau dengan kata lain mampu beradaptasi dengan berbagai perubahan sehingga meminimalkan stress yang dialami. Ketika lansia mampu menerima dan menyesuaikan diri dengan berbagai peristiwa yang mengubah kehidupannya maka hal ini berarti pula tingkat stres yang dialami akan menurun (Ummah, 2016).

\section{SIMPULAN}

Berdasarkan hasil penelitian, maka didapatkan sebagian besar lansia di Balai Penyantunan Sosial Lanjut Usia Terlantar Senja Cerah mengalami stress fisik ringan. Sebagian besar lansia lansia di Balai Penyantunan Sosial Lanjut Usia Terlantar Senja Cerah mengalami stress psikologis ringan.

\section{DAFTAR PUSTAKA}

Arbi, D. K. A. dan Ambarini, T., K. 2018. Terapi Brief Mind fulness-Based Body Scan untuk Menurunkan Stres Atlet Bola Basket Wanita Profesional. Jurnal Psikologi dan Kesehatan Mental. 6 (1): 1-12

Azizah, R dan R. D. Hartatnti. 2016. Hubungan antara Tingkat Stres dengan Kualitas Hidup Lansia Hipertensi di Wilayah Kerja Puskesmas Wonopringgo Pekalongan. The 4 th University Research Coloqium. 261278.

Badan Pusat Statistik. RI. 2013. Statistik Penduduk Lanjut Usia Indonesia 2013: Hasil Sensus Penduduk 2013. Jakarta : BPS. 
Bandiyah, S. 2009. Lanjut Usia dan Keperawatan Gerontik. Yogyakarta : Nuha Medika.

Dahroni, Arisdiani, T dan Y. P. Widiastuti. 2017. Hubungan Antara Stres Emosi dengan Kualitas Tidur Lansia. Jurnal Keperawatan 5 (2): 68-71.

Fatmawati, V dan M. A. Imron. 2017. Perilaku Koping pada Lansia yang Mengalami Penurunan Gerak dan Fungsi. Intuisi, Jurnal Psikologi Ilmiah 9 (1): 26-38.

Hidaayah, N. 2013. Stress pada Lansia Menjadi Faktor Penyebab dan Akibat Terjadinya Penyakit. The Journal of Health Sciences 6 (2): 1-8

Hurlock, E.B. 2004. Developmental psychology: a life span approach. 5th edition. Alih bahasa: Istiwidayanti dan Soedjarwo. Jakarta: Erlangga.

Karepowan, S. R., Wowor, Man Katuuk,M. 2018. Hubungan Kemunduran Fisiologis dengan Tingkat Stres Pada Lanjut Usia di Puskesmas Kakaskasen Kecamatan Tomohon Utara. Jurnal keperawatan 6 (1): 1-7.

Musradinur. 2016. Stres dan Cara Mengatasinya dalam Perspektif Psikologi. Jurnal Edukasi 2 (2): 183200.

Padila. 2013. Buku Ajar Keperawatan Gerontik. Nuha Medika: Bengkulu.

Putri, R. D. 2012. Perbedaan Tingkat Stres Pada Lansia Yang Bertempat Tinggal di Rumah Dan Di UPT Pelayanan Sosial Lanjut Usia Bondowoso. Skripsi. Program Studi Ilmu Keperawatan Universitas Jember. Jember

Rahman, S. 2016. Faktor-faktor yang Mendasari Stres pada Lansia. Jurnal Pendiidkan Indonesia 16 (1): 1-7.
Sary, Y.N.E., 2015. Buku Ajar Psikologi Pendidikan. Yogyakarta: Parama Publishing.

Selo, J., E. Candrawati dan R. M. Putri. 2017. Perbedaan Tingkat Stres pada Lansia di Dalam dan di Luar Panti Werdha Pangesti Lawang. Nursing News 2 (3): 522-533.

Ummah, A. C. 2016. Hubungan Kebutuhan Spiritual dengan Kualitas Hidup pada Lansia di Panti Wredha Kota Semarang. Skripsi. Universitas Diponegoro. Semarang. 